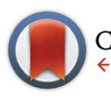

CrossMark

\&lick for updates

Cite this: DOI: $10.1039 / \mathrm{c} 5 \mathrm{dt} 02211 \mathrm{~h}$

\title{
The effect of potential supramolecular-bond promoters on the DNA-interacting abilities of copper-terpyridine compounds $\uparrow$
}

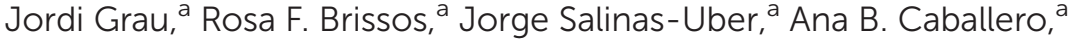 \\ Amparo Caubet, ${ }^{* a}$ Olivier Roubeau, ${ }^{b}$ Luís Korrodi-Gregório, ${ }^{c, d}$ \\ Ricardo Pérez-Tomás ${ }^{c}$ and Patrick Gamez ${ }^{\star a, e}$
}

\begin{abstract}
Three copper(II) coordination compounds have been prepared from three different $2,2^{\prime}: 6^{\prime}, 2^{\prime \prime}$-terpyridinebased ligands, which have been selected to investigate the potential role of supramolecular interactions on the DNA-interacting and cytotoxicity properties of the corresponding metal complexes. Hence, the ligands 4'-((naphthalen-2-yl)methoxy)-2,2':6',2"-terpyridine (Naphtpy) and 4'-((1H-benzo[d]imidazol2-yl)methoxy)-2,2':6',2"-terpyridine (Bimztpy) have been synthesized from commercially-available $4^{\prime}$-chloro-2,2':6',2'-terpyridine (Cltpy), and their copper(II) complexes have been obtained by reaction with copper(II) nitrate. The DNA-interacting abilities of the corresponding compounds $\left[\mathrm{Cu}(\mathrm{Cltpy})\left(\mathrm{H}_{2} \mathrm{O}\right)\left(\mathrm{NO}_{3}\right)_{2}\right]$ (1), [Cu(naphtpy) $\left.\left(\mathrm{NO}_{3}\right)\left(\mathrm{H}_{2} \mathrm{O}\right)\right]\left(\mathrm{NO}_{3}\right)(\mathrm{MeOH})\left(\right.$ 2) and $\left[\mathrm{Cu}\left(\right.\right.$ bimztpy) $\left.\left(\mathrm{NO}_{3}\right)\left(\mathrm{H}_{2} \mathrm{O}\right)\right]\left(\mathrm{NO}_{3}\right)$ (3) have been investigated using different techniques, and cytotoxicity assays with several cancer cell lines have revealed interesting features, viz. the more efficient complex is $\mathbf{2}$, which although it does not act as a DNA cleaver, displays the most effective DNA-interacting and cytotoxic properties, compared to 1 and $\mathbf{3}$.
\end{abstract}

Received 10th June 2015 Accepted 31st July 2015

DOI: $10.1039 / \mathrm{c} 5 \mathrm{dt} 02211 \mathrm{~h}$ www.rsc.org/dalton one of the most used chemotherapy drugs worldwide. ${ }^{4-6}$ It is well known that cisplatin interferes with DNA through binding to guanine bases, ${ }^{7-10}$ inducing kinks in the biomolecule, ${ }^{11,12}$ which leads to cell death (apoptosis). ${ }^{13,14}$

This platinum drug has several drawbacks, i.e. it is only efficient for a limited number of cancers, ${ }^{15,16}$ some tumours may exhibit acquired or intrinsic resistance to it, ${ }^{17,18}$ and it produces severe side effects, such as nausea, nephrotoxicity, ototoxicity or myelosuppression. ${ }^{19,20}$ Therefore, the search for improved drugs is a perpetual scientific challenge; for instance, three new platinum-containing compounds have been developed and marketed, viz. carboplatin, oxaliplatin and nedaplatin. ${ }^{21,22}$

Alternative approaches have been developed as well to circumvent these drawbacks, exploiting other metal ions. ${ }^{23,24}$ One possible strategy consists of using the redox properties of a metallic centre to generate reactive oxygen species (ROS) that will be able to cleave DNA, for example via oxidation of the deoxyribose unit. ${ }^{25,26}$ Actually, this approach is based on the DNA-cleaving properties of bleomycins, a family of natural products with antitumour activity, which originates from their aptitude to bind transition metals like iron and copper, and to subsequently produce ROS in the presence of a one-electron reductant. ${ }^{27-29}$ Hence, various synthetic coordination compounds mimicking the nuclease activity of bleomycins have 


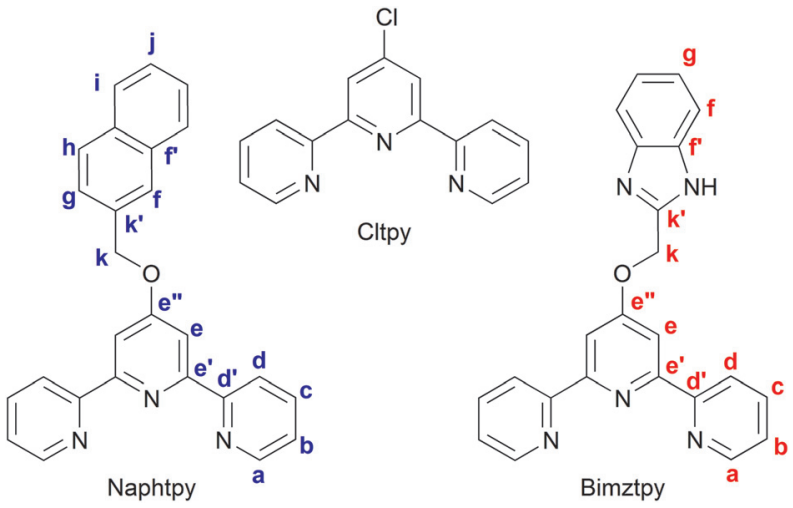

Fig. 1 Representations of the tpy-based ligands $4^{\prime}$-chloro-2,2':6',2"terpyridine (Cltpy), 4'-((naphthalen-2-yl)methoxy)-2,2':6',2"'-terpyridine (Naphtpy) and $4^{\prime}-((1 H$-benzo[d]imidazol-2-yl)methoxy)-2,2':6',2"-terpyridine (Bimztpy), together with the labels used for the assignment of the NMR peaks (in blue for Naphtpy and in red for Bimztpy; see the Experimental section).

been reported, ${ }^{30,31}$ the most studied being (methidiumpropylEDTA)iron(II ${ }^{32,33}$ and bis-phenanthroline copper(I). ${ }^{34,35}$

$2,2^{\prime}: 6^{\prime}, 2^{\prime \prime}$-Terpyridine (tpy) is a tridentate ligand that has widely been used to generate transition-metal complexes. ${ }^{36}$ Actually, tpy-based metal complexes have found numerous remarkable applications in various areas of chemistry. ${ }^{37-41}$ In the field of anticancer drug design, the utilization of tpycontaining systems is receiving a great deal of attention, ${ }^{42-44}$ for instance due to their recently recognized propensity to stabilize G-quadruplex structures. ${ }^{45-47}$

In the present study, three different 4 -substituted tpy ligands have been used to generate copper(II) complexes, and their DNA-interacting properties have been investigated and compared. The ligands naphtpy and bimztpy (Fig. 1) have been prepared from commercially available Cltpy, and have been designed to favour $\pi-\pi$ interactions (the naphthyl group in naphtpy) and hydrogen-bonding contacts (the benzimidazole ring in bimztpy). Hence, Cltpy does not possess an additional group favouring supramolecular $\pi-\pi$ interactions while both naphtpy and bimztpy have an aryl substituent that may promote $\pi$-stacking, and bimztpy can also act as a hydrogen donor and/or a hydrogen acceptor moiety.

\section{Results and discussion}

\section{Ligand synthesis}

The ligands naphtpy and bimztpy were prepared by reaction of respectively 2-naphthalenemethanol or benzimidazol-2-methanol with Cltpy in DMSO in the presence of potassium hydroxide, applying a synthetic procedure described in the literature (see the Experimental section). ${ }^{48}$ The single-crystal X-ray structure of naphtpy could be obtained; the corresponding crystallographic data are given in Table $\mathrm{S} 1$ and a representation of its molecular structure is depicted in Fig. S1 (see the ESI $\dagger$ ).

\section{Complex synthesis and structure}

The reaction of one equivalent of copper(II) nitrate trihydrate with one equivalent of the ligand in methanol at $50{ }^{\circ} \mathrm{C}$ leads to the formation of the corresponding coordination compound. All complexes are isolated as microcrystalline powders by filtration and are fully characterized (see the Experimental section).

Single crystals of $\left[\mathrm{Cu}(\mathbf{C l t p y})\left(\mathrm{H}_{2} \mathrm{O}\right)\left(\mathrm{NO}_{3}\right)_{2}\right]$ (1) can be obtained by crystallization in methanol. A representation of the molecular structure of $\mathbf{1}$, determined by X-ray diffraction, is shown in Fig. S2 (ESI $\dagger$ ). The crystal structure of $\mathbf{1}$ has been reported previously; ${ }^{49}$ the complex is octahedral, with the tpy ligand and the water molecule occupying the equatorial plane and the nitrate ions located at the axial positions. ${ }^{49}$ In the crystal lattice, the molecules are associated through $\pi-\pi$ interactions, generating a supramolecular chain along the crystallographic axis (Fig. S3a, ESI $\dagger$ ). Close contacts between pyridine rings are observed, as evidenced by the short $\mathrm{C} 2 \cdots \mathrm{C} 7 \mathrm{~g}$ distance of 3.375(3) $\AA$, which is slightly below the sum of the van der Waals radii of two carbon atoms, namely $3.40 \AA$. In addition, strong hydrogen bonds (donor...acceptor distance of 2.765(2) ^̊) occur between neighbouring complexes through the water molecule and nitrate ions, producing a supramolecular chain along the crystallographic $c$ axis (Fig. S3b, ESI $\dagger$ ).

The reaction of one equivalent of naphtpy with one equivalent of copper(II) nitrate trihydrate yields compound $\left[\mathrm{Cu}\left(\right.\right.$ naphtpy) $\left.\left(\mathrm{NO}_{3}\right)\left(\mathrm{H}_{2} \mathrm{O}\right)\right]\left(\mathrm{NO}_{3}\right)(\mathrm{MeOH})$ (2). A representation of the molecular structure of 2 , determined by single-crystal X-ray diffraction, is depicted in Fig. 2. Crystallographic and refinement parameters are summarized in Table S2 (ESI $\dagger$ ), and selected coordination bond lengths and angles are listed in Table S3 (ESI $\dagger$ ). First, it should be mentioned that the crystal lattice of this compound contains two slightly different copper centers, with only some minor divergences regarding coordination bond lengths and angles. Therefore, only one coordination geometry is described in detail. The geometry about the metal ion is a distorted square pyramid, characterized by $\tau_{5}$ values of 0.03 and 0.12 (for the two copper ions). ${ }^{50}$ The basal plane is formed by the three nitrogen atoms from the naphtpy ligand and a water molecule, the apical position being occu-

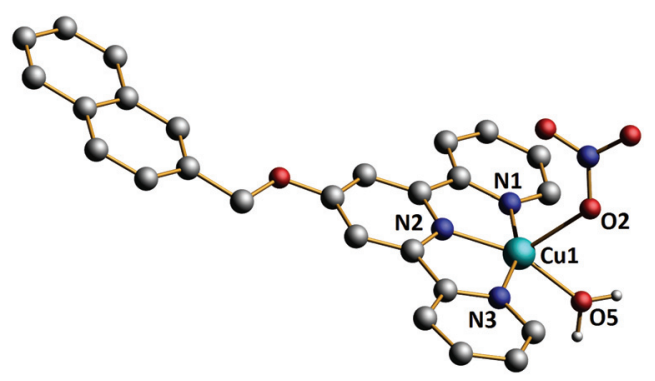

Fig. 2 Representation of the molecular structure of the complex cation 2 with the partial atom-numbering scheme. The hydrogen atoms (except for those of the coordinated water molecule), the lattice methanol molecule and nitrate ion are omitted for clarity. 
pied by a nitrate anion (Fig. 2). The $\mathrm{Cu}-\mathrm{N}, \mathrm{Cu}-\mathrm{O}_{\text {water }}$ and $\mathrm{Cu}-\mathrm{O}_{\text {nitrate }}$ bond distances are similar to those found for $\mathbf{1}$, the nitrate ion being slightly closer in 2 (compared to 1 , see Table S3 $\dagger$ ). The basal angles, varying from 79.61(9) to $99.80(9)^{\circ}$ (Cu1, Table S3†), reflect the geometrical distortion, which is mostly due to the small bite angle of the tpy unit.

An examination of the crystal packing of 2 reveals that the naphthyl group is largely involved in $\pi-\pi$ interactions (as expected, this ligand has been designed to favour the occurrence of such supramolecular contacts).

Indeed, molecules of 2 assemble in a head-to-tail fashion by means of strong stacking interactions as reflected by short $\mathrm{C}_{\text {tpy }} \cdots \mathrm{C}_{\text {naphthyl }}$ contact distances, ranging from $3.320(3)$ to 3.400 (4) ̊ (Fig. 3 and Table S3, ESI†). Furthermore, as occurring in the solid-state structure of $\mathbf{1}$, the coordinated water molecule acts as an $\mathrm{H}$-donor group for a nitrate ion of an adjacent molecule, forming a dimer $(\mathrm{O} 10 \cdots \mathrm{O} 2$ and $\mathrm{O} 5 \cdots \mathrm{O} 7$; Fig. 4 and Table S3, ESI†).

Besides, the coordinated water molecule is also strongly bonded to a lattice nitrate anion (the corresponding donor...acceptor contact distances amount to 2.646(3) and 2.630(3) A; see Table S3 and Fig. S4, ESI $\dagger$ ), giving rise to the formation of a supramolecular chain (of dimers) along the crystallographic $a$ axis (Fig. S4, ESI $\dagger$ ).

The reaction of one equivalent of bimztpy with one equivalent of copper(II) nitrate trihydrate generates copper complex 3, whose molecular structure could not be determined by X-ray diffraction analysis. Indeed, up to now, all attempts to get single

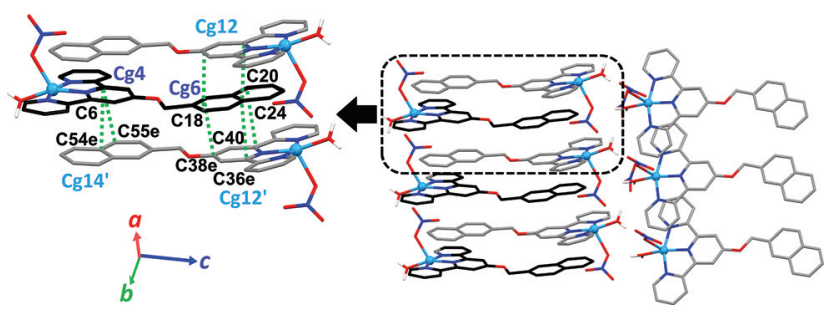

Fig. 3 Views of the crystal packing of 2 illustrating the supramolecular arrangement of the molecules through $\pi-\pi$ interactions between naphthyl and tpy groups. Cg4 $\cdots \mathrm{Cg} 14^{\prime}=3.872(1)$ and $\mathrm{Cg} 6 \cdots \mathrm{Cg} 12^{\prime}=$ 3.582(1) Å. Symmetry operation: $e=-1 / 2+x, 1 / 2-y, 1 / 2+z$.

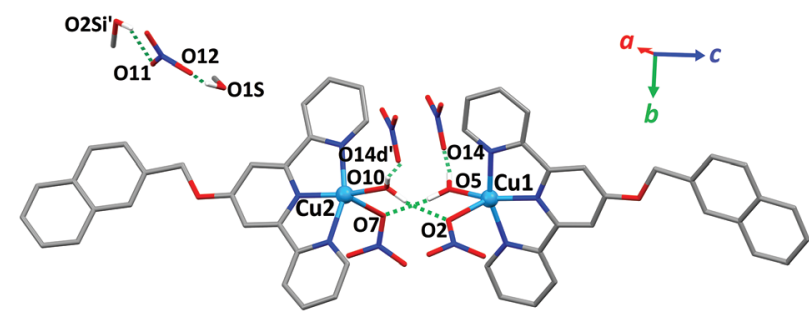

Fig. 4 View of the crystal packing of 2 showing the $\mathrm{H}$-bonding network connecting two molecules $(\mathrm{O} 10 \cdots \mathrm{O} 2=2.701(3)$ and $\mathrm{O} 5 \ldots \mathrm{O} 7=2.737(3)$ $\AA)$, and the interaction of a lattice nitrate ion with two water molecules (O1S $\cdots \mathrm{O} 12=2.895(7)$ and O2S $\cdots \mathrm{O} 11=2.897(7) \AA$ ) $)$. Symmetry operations: $d=1+x, y, z ; i=1-x, 1-y, 1-z$. crystals of the compound failed, unfortunately. However, elemental analysis and mass-spectrometry data (see the Experimental section) of the microcrystalline product allow its formulation as $\left[\mathrm{Cu}(\right.$ bimztpy $\left.)\left(\mathrm{NO}_{3}\right)\left(\mathrm{H}_{2} \mathrm{O}\right)\right]\left(\mathrm{NO}_{3}\right)(3)$. Therefore, it may be expected that the coordination environment of the metal centre in $\mathbf{3}$ is analogous to those of $\mathbf{1}$ and $\mathbf{2}$ (Fig. S2, ESI $\dagger$ ).

\section{UV-Vis spectroscopy}

Molecular absorption spectroscopy in the ultraviolet (UV) and visible (vis) region is an efficient tool to investigate the binding of (coordination) compounds to DNA. ${ }^{51,52}$ Therefore, absorption spectra have been recorded at a constant complex concentration of $25 \mu \mathrm{M}$ and with increasing amounts of calf-thymus DNA (ct-DNA), from 0 to $100 \mu \mathrm{M}$. The corresponding spectra for $\mathbf{1}$ are shown in Fig. 5. Those for $\mathbf{2}$ and $\mathbf{3}$ are depicted in Fig. S5 (ESI $\dagger$ ).

Absorption bands in the region 300-400 nm, which are attributed to metal-to-ligand charge transfer (MLCT), were used to monitor the interaction of 1-3 with duplex DNA. Hypochromism is clearly observed while increasing quantities of 1 are added to ct-DNA (Fig. 5 and Table 1), which suggests an electronic interaction between the binding complex and the biomolecule. $^{53}$ No redshifts of the absorption bands are observed; actually, a shift towards a longer wavelength is indicative of an intercalation binding mode (through stacking interactions). ${ }^{54,55}$ Therefore, 1 does not seem to intercalate between DNA base pairs; rather it appears that $\mathbf{1}$ tends to (mostly) interact electrostatically with the double helix. ${ }^{56,57}$

The magnitude of the binding strength may be estimated through the determination of the intrinsic binding constant $K_{\text {b, applying eqn (1): }}{ }^{56}$

$$
\frac{[\mathrm{DNA}]}{\varepsilon_{\mathrm{a}}-\varepsilon_{\mathrm{f}}}=\frac{[\mathrm{DNA}]}{\varepsilon_{0}-\varepsilon_{\mathrm{f}}}+\frac{1}{K_{\mathrm{b}}\left(\varepsilon_{0}-\varepsilon_{\mathrm{f}}\right)}
$$

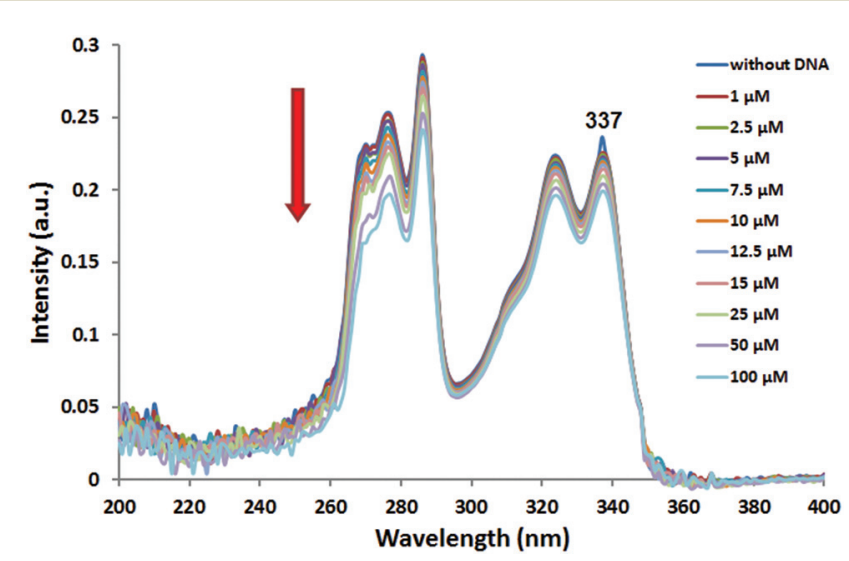

Fig. 5 Absorption spectra of 1 in Tris- $\mathrm{HCl}$ buffer $(\mathrm{pH}=7.2)$ upon addition of ct-DNA. Complex concentration: $25 \mu \mathrm{M}$; [ct-DNA]: 0-100 $\mu \mathrm{M}$. The concentration of ct-DNA was determined from its absorption intensity at $260 \mathrm{~nm}$ with a molar extinction coefficient of $6600 \mathrm{M}^{-1} \mathrm{~cm}^{-1}$. The MLCT band at $\lambda=337 \mathrm{~nm}$ was used to determine $K_{\mathrm{b}}$. The red arrow shows the decrease in the absorption intensity with the increase in concentration of ct-DNA. 
Table 1 Intrinsic binding constants $K_{\mathrm{b}}$ and \% hypochromism for complexes 1-3 interacting with ct-DNA ${ }^{a}$

\begin{tabular}{llll}
\hline Complex & $K_{\mathrm{b}}{ }^{b}\left(10^{5} \mathrm{M}^{-1}\right)$ & $\log K_{\mathrm{b}}$ & $\%$ Hypochromism \\
\hline $\mathbf{1}$ & $1.90 \pm 0.16$ & 5.28 & $16^{c}$ \\
2 & $3.60 \pm 0.11$ & 5.56 & $13(32)^{d}$ \\
3 & $2.08 \pm 0.09$ & 5.32 & $6(12)^{e}$
\end{tabular}

${ }^{a}$ Linear $[\mathrm{DNA}] /\left(\varepsilon_{\mathrm{a}}-\varepsilon_{\mathrm{f}}\right)$ vs. [DNA] plots are obtained for [complex]: [DNA] ratio $\leq 1: 1 .{ }^{b} K_{\mathrm{b}}$ is obtained from the ratio of the slope to the intercept $(\lambda=337 \mathrm{~nm}(\mathbf{1}), \lambda=330 \mathrm{~nm}(2)$ and $\lambda=328 \mathrm{~nm}$ (3)). The $K_{\mathrm{b}}$ errors have been determined from the measurement in triplicate for each complex. ${ }^{c}$ At $\lambda=337 \mathrm{~nm} .{ }^{d}$ At $\lambda=330 \mathrm{~nm}$ (at $\lambda=$ $222 \mathrm{~nm}) .{ }^{e}$ At $\lambda=328 \mathrm{~nm}$ (at $\left.\lambda=204 \mathrm{~nm}\right)$.

where [DNA] is the concentration of ct-DNA in base pairs, $\varepsilon_{\mathrm{a}}$ is the extinction coefficient observed at the given ct-DNA concentration, $\varepsilon_{\mathrm{f}}$ is the extinction coefficient of the free complex in solution $\left(A_{\mathrm{obs}} /[\right.$ complex $\left.]\right)$, and $\varepsilon_{0}$ is the extinction coefficient for the compound in the fully bound form.

The binding constant $K_{\mathrm{b}}$ for 1 amounts to $1.90 \times 10^{5} \mathrm{M}^{-1}$ (Table 1), hence suggesting a strong affinity of the compound for ct-DNA.

Similar features are observed for compound 2 (Fig. S5a, ESI $\dagger$ ), since comparable hypochromism without wavelength shifting occurs (the \% hypochromism value is 13 for 2 while it is 16 for 1 ; see Table 1 ). However, the DNA-binding abilities of 2 are noticeably greater than those of $\mathbf{1}\left(K_{\mathrm{b}}(\mathbf{1})=1.90 \times 10^{5} \mathrm{M}^{-1}\right.$ and $\left.K_{\mathrm{b}}(2)=3.60 \times 10^{5} \mathrm{M}^{-1}\right)$. This difference most likely arises from the additional functional group at the $4^{\prime}$-position of the terpyridine unit (ligand naphtpy; see Fig. 1), namely the naphthyl moiety. In fact, compared to the UV-vis spectra of $\mathbf{1}$ (Fig. 5), those of 2 exhibit a strong absorption band at $\lambda=$ $222 \mathrm{~nm}$ (which is absent for 1), which can be ascribed to $\pi-\pi^{*}$ transitions of the naphthyl group (Fig. S5a, ESI†). This absorption band is strongly affected by the binding to ct-DNA, as reflected by the corresponding hypochromism of $32 \%$ (Table 1). So, the naphthyl ring apparently is strongly involved in the binding of the copper complex to DNA, probably through $\pi$-stacking interactions (actually, the ligand naphtpy has been designed to favour such supramolecular contacts).

Compound 3 shows DNA-binding abilities which are comparable to those of 1 , viz. $K_{\mathrm{b}}(3)=2.08 \times 10^{5} \mathrm{M}^{-1}$ and $K_{\mathrm{b}}(1)=$ $1.90 \times 10^{5} \mathrm{M}^{-1}$ (Table 1). However, the hypochromism induced by 3 is significantly lower than that caused by 1 (i.e. 6 vs. 16\%, see Table 1), thus indicating that the binding mode of the two compounds is different. Furthermore, the band of 3 at $\lambda=$ $204 \mathrm{~nm}$ (Fig. S5b, ESI $\dagger$ ), attributable to $\pi-\pi^{*}$ transitions of the benzimidazole group (as these bands are not observed for the parent ligand Cltpy; see Fig. 5), are not strongly altered, in contrast to the corresponding ones for compound 2 (hypochromism of $12 v s .32 \%$, see Table 1). These data thus suggest that the DNA-binding of 3 is different from those of 1 and 2. Since 3 possesses hydrogen-donor and hydrogen-acceptor groups (while 1 and 2 do not), it may be reasonably considered that hydrogen bonds play an important role in the binding of 3 to ct-DNA (as anticipated through ligand design).

\section{Fluorescence spectroscopy}

Competitive binding studies using ethidium bromide (EB) bound to ct-DNA and using complexes as fluorescence quenchers may provide further comparative information regarding their DNA-binding affinities. It is well known that EB is a DNAintercalating compound that fluoresces when it is bound to the duplex biomolecule. ${ }^{58,59}$ Thus, displacement of EB by a compound that binds to DNA will result in fluorescence quenching. ${ }^{60}$

Fluorescence spectra have been recorded at constant concentrations of EB and ct-DNA, namely $25 \mu \mathrm{M}$, by adding increasing amounts of the studied complex, viz. in the concentration range 5-200 $\mu \mathrm{M}$. For the three copper(II) complexes, a decrease in the emission intensity is observed. The quenching spectra for compound $\mathbf{1}$ are shown in Fig. 6, which are representative of the other compounds investigated in the present study (they are complexes 2 and 3; see Fig. S6, ESI $\dagger$ ). The release of $\mathrm{EB}$ in all cases confirms that these coordination compounds indeed interact with ct-DNA, as also indicated by the UV-vis measurements (see above).

To compare the affinity of complexes 1-3 towards ct-DNA, their quenching efficiency has been assessed by determining the corresponding Stern-Volmer constant $K_{\mathrm{SV}}$, applying eqn (2)

$$
\frac{I_{0}}{I}=1+K_{\mathrm{SV}}[\text { complex }]
$$

where $I_{0}$ is the initial fluorescence intensity of EB (bound to ctDNA) and $I$ is the fluorescence intensity in the presence of the complex (leading to EB displacement). A plot of $I_{0} / I$ versus [complex] gives a straight line whose slope is equal to $K_{\mathrm{Sv}}$. The $K_{\mathrm{SV}}$ constants thus obtained for complexes 1-3 are listed in Table 2 . The trend of the $K_{\mathrm{SV}}$ values follows that observed for the intrinsic binding constants $K_{\mathrm{b}}$ (see above). Indeed, the highest value, i.e. $4.97 \times 10^{3} \mathrm{M}^{-1}$, is found for compound 2 (Table 2), which also shows the greatest $K_{\mathrm{b}}$ (compared to 1 and 3; see Table 1). Thus, 2 that has a naphthyl group (ligand

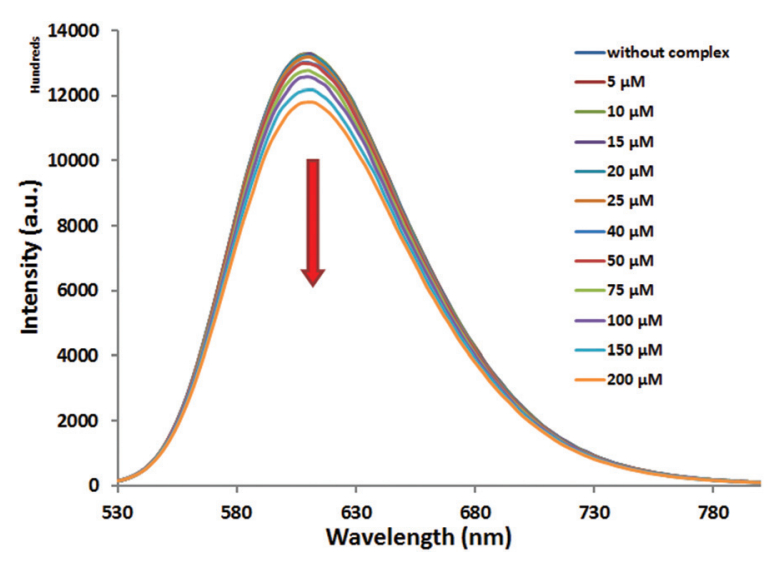

Fig. 6 Emission spectra of the DNA-EB complex $(25 \mu M), \lambda_{\text {exc }}=514 \mathrm{~nm}$, $\lambda_{\mathrm{em}}=610 \mathrm{~nm}$, upon addition of increasing amounts of $1(5-200 \mu \mathrm{M})$. The red arrow shows the diminution of the emission intensity with the increase in concentration of 1 . 
Table 2 Stern-Volmer constants $K_{\mathrm{Sv}}$ determined for complexes 1-3 competing with ethidium bromide ${ }^{a}$

\begin{tabular}{lll}
\hline Complex & $K_{\mathrm{SV}}\left(10^{3} \mathrm{M}^{-1}\right)$ & $\log K_{\mathrm{SV}}$ \\
\hline $\mathbf{1}$ & $1.45 \pm 0.05$ & 3.16 \\
$\mathbf{2}$ & $4.97 \pm 0.33$ & 3.70 \\
$\mathbf{3}$ & $2.45 \pm 0.20$ & 3.39
\end{tabular}

${ }^{a} K_{\mathrm{SV}}$ is obtained from the slope of the linear Stern-Volmer plot. The $K_{\mathrm{SV}}$ errors have been determined from the measurement in triplicate for each complex.

naphtpy) shows the best EB-displacing abilities. Taking into account that EB is a DNA-intercalating molecule, it may be assumed that this higher efficiency arises from the naphthyl unit, which may replace EB between base pairs (actually, UVvis measurements show that the $\pi-\pi^{*}$ transitions corresponding to this group display the highest percentage of hypochromism upon DNA binding; see above and Fig. S5a, ESI†).

The $K_{\mathrm{SV}}$ values for $\mathbf{1}$ and $\mathbf{3}$ are lower, and the tendency observed is analogous to that noticed for the binding constants $K_{\mathrm{b}}$ (see above; Table 1 ). Actually, 3 appears to bind to ctDNA with a slightly better efficiency than 1 (2.45 vs. $1.45 \times 10^{3}$ $\mathbf{M}^{-1}$, Table 2). It can be mentioned here that displacement of EB by a molecule does not imply that the latter acts as an intercalator (like EB). Indeed, electrostatic interactions or groove binding may be sufficient to alter significantly the conformation of the DNA double helix, which may result in the release of EB. ${ }^{61,62}$ Therefore, the benzimidazole unit of the ligand bimztpy may interact with DNA by means of electrostatic interactions, namely hydrogen bonds involving its $\mathrm{N}-\mathrm{H}$ group (which is not the case for Cltpy), provoking a change of the DNA structure with concomitant loss of EB molecules.

\section{Gel electrophoresis}

Agarose gel electrophoresis has been subsequently employed to observe directly the interaction of compounds 1-3 with plasmid DNA. Hence, the potential DNA-cleaving abilities of 1-3 were evaluated by electrophoretic mobility measurements with pBR322 plasmid DNA. A reducing agent, namely ascorbic acid, has been used as well to simulate the reducing environment found in most cellular compartments (the physiological concentrations of ascorbic acid range from 100 to $400 \mu \mathrm{M}$ ). The generation of copper(I) species will permit the potential formation of reactive oxygen species (ROS) that are capable of cleaving DNA. The corresponding agarose gels are depicted in Fig. 7. First, it should be noted that complexes 1 and 3 exhibit similar behaviour while that of $\mathbf{2}$ is clearly distinct. For $\mathbf{1}$ (Fig. 7a, left), without a reducing agent, the complex concentrations of $5-20 \mu \mathrm{M}$ do not affect the DNA since the bands observed (lanes 2-4), corresponding to forms I and II (supercoiled and circular nicked forms, respectively), and their intensity are similar to those of the native biomolecule (lane 1). From a complex concentration of $40 \mu \mathrm{M}$ (lane 5), a clear increase in the intensity of the band for form II is noted, which is associated with a vanishing of the band corres-

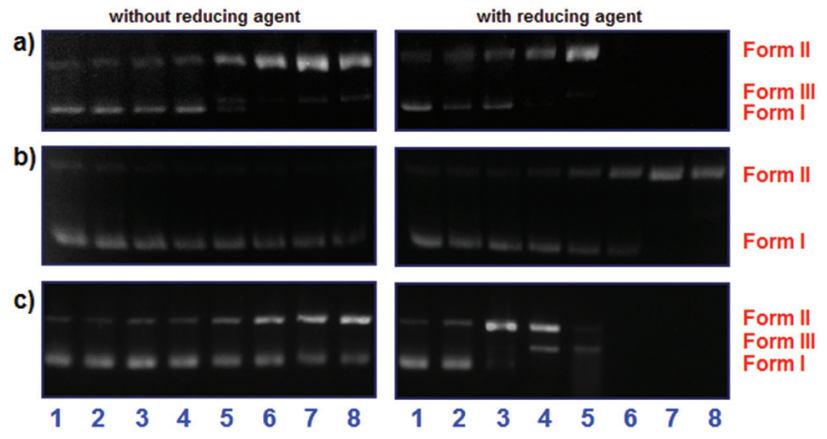

Fig. 7 Agarose gel electrophoresis images of pBR322 plasmid DNA (15 $\mu \mathrm{M}$ b.p.) incubated for $1 \mathrm{~h}$ at $37^{\circ} \mathrm{C}$ with increasing concentrations of (a) complex 1, (b) complex 2 and (c) complex 3, without (left) or in the presence of a reducing agent (right), i.e. ascorbic acid $(100 \mu \mathrm{M})$, during an additional incubation time of $1 \mathrm{~h}$ (lanes 2-8). Left: lane 1: pure plasmid DNA; lane 2: [complex] = $5 \mu \mathrm{M}$; lane 3: [complex] $=10 \mu \mathrm{M}$; lane 4: [complex] $=20 \mu \mathrm{M}$; lane 5: [complex] $=40 \mu \mathrm{M}$; lane 6: [complex] = $60 \mu \mathrm{M}$; lane 7: [complex] $=80 \mu \mathrm{M}$; lane 8: [complex] $=100 \mu \mathrm{M}$. Right: Lane 1: pure plasmid DNA; lane 2: pBR322 plasmid DNA + ascorbic acid $(100 \mu \mathrm{M})$; lane 3: [complex] = $5 \mu \mathrm{M}$; lane 4: [complex] = $10 \mu \mathrm{M}$; lane 5: [complex] $=20 \mu \mathrm{M}$; lane 6: [complex] $=40 \mu \mathrm{M}$; lane 7: [complex] = $60 \mu \mathrm{M}$; lane 8: [complex] $=80 \mu \mathrm{M}$.

ponding to form I; in addition, a new band appears between those of forms I and II, which is ascribed to form III (linear form, lane 5) that is produced when both DNA strands are broken. It thus appears that $\mathbf{1}$ acts as an efficient DNA cleaver when concentrations superior to $40 \mu \mathrm{M}$ are used, as evidenced in lanes 5-8 (Fig. 7a, left), where an increase in the band intensity for both forms II and III is noticed together with the complete disappearance of the band corresponding to form I. In the presence of a reducing agent (Fig. 7b, right), comparable features are observed but the DNA cleavage is achieved at lower complex concentrations (Fig. 7a, right); indeed, the complete loss of form $\mathrm{I}$ is obtained for a complex concentration of $20 \mu \mathrm{M}$ (lane 5, Fig. 7a, right), while $60 \mu \mathrm{M}$ of 1 are required without ascorbic acid (lane 6, Fig. 7a, left). Moreover, the plasmid DNA is completely degraded when using complex concentrations above $40 \mu \mathrm{M}$ (no bands are observed in lanes 6-8), and this does not occur without the reducing agent (with complex concentrations up to $100 \mu \mathrm{M}$; Fig. 7a, left). Consequently, the DNA-cleaving properties of $\mathbf{1}$ are improved in the presence of ascorbic acid, most likely as the result of the production of higher amounts of ROS.

For 2, a drastically different behaviour is observed (Fig. 7b). Actually, without a reducing agent, the intensity of the bands (for both form I and form II) decreases when the concentration of the complex is increased, and the generation of form III does not take place (Fig. 7b, left). These results are indicative of the occurrence of strong DNA-2 interactions, ${ }^{56}$ without strand cleavage. Compound 2 may simply act as an efficient DNA binder (in fact, the largest $K_{\mathrm{b}}$ and $K_{\mathrm{SV}}$ values have been obtained with 2; see above), giving rise to the formation of voluminous DNA-complex species such as DNA dimers, trimers and so on (bound to metal complexes), which 
precipitate and result in the vanishing of the bands. When ascorbic acid is used (Fig. 7b, right), vanishing of the bands also takes place (lanes 3 and 4), but some cleavage is observed as well, since the intensity of the band ascribed to form II increases with the complex concentration (concentrations of 2 above $20 \mu \mathrm{M}$; lanes 5-8), and form I is eliminated when a complex concentration above $60 \mu \mathrm{M}$ is used (lanes 7 and 8; Fig. 7b, right). Accordingly, some quantities of ROS are generated that begin to affect the plasmid DNA.

Complex 3 exhibits a behaviour that is analogous to that of 1. Without a reducing agent (Fig. 7c, left), the compound does not affect the biomolecule with concentrations up to $20 \mu \mathrm{M}$ (lanes 2-4). Above this concentration, the band corresponding to form II intensifies progressively with the concentration, while that of form I decreases (lanes 5-8). In the present case, however, emergence of form III is not observed as for $\mathbf{1}$. Thus, without ascorbic acid, 3 appears to be a less efficient DNA cleaver than 1. In contrast, when a reducing agent is added, the cleaving properties of $\mathbf{3}$ are significantly better than those of 1 (Fig. 7a and 7c, right); indeed, form III is already generated with $5 \mu \mathrm{M}$ of 3 (Fig. 7c right, lane 3), whereas $10 \mu \mathrm{M}$ of 3 are required to detect linear DNA (Fig. 7a right, lane 4). DNA form I is completely damaged with a complex concentration of $10 \mu \mathrm{M}$ (lane 4), while it is $20 \mu \mathrm{M}$ for 1 (lane 5). Above a complex concentration of $40 \mu \mathrm{M}$, the plasmid DNA is completely degraded (lanes 6-8).

In summary, the electrophoretic results corroborate the stronger DNA-binding affinity of 2 observed by UV-Vis and fluorescence spectroscopy (see above). Interestingly, $\mathbf{1}$ and $\mathbf{3}$ are very efficient DNA cleavers, contrary to 2 . It appears that the strong binding of 2 to DNA avoids DNA degradation by ROS; the ROS-generation abilities of 2 seem to be "silenced" through DNA binding.

We have also performed similar gel-electrophoresis studies with the free ligands in the absence and presence of a reducing agent, namely ascorbic acid. As is evidenced in Fig. 8 (experiments carried out without a reducing agent), Cltpy, Naphtpy and Bimztpy do not affect at all the electrophoretic mobilities of pBR322 plasmid DNA. The same features are observed in the presence of ascorbic acid (results not shown).

\section{AFM studies}

pBR322 plasmid DNA was incubated at $37{ }^{\circ} \mathrm{C}$ for 1 hour with the different complexes ([complex $]=5 \mu \mathrm{M})$ in $40 \mathrm{mM}$ HEPES$10 \mathrm{mM} \mathrm{MgCl}{ }_{2}$ buffer, as for the corresponding gel electrophoresis experiments (see the Experimental section), for comparison purposes. The atomic-force microscopy (AFM) images obtained are presented in Fig. 9. Fig. 9a shows the original morphology of the pBR322 plasmid DNA used for these studies, without (left) and with (right) the reducing agent (i.e. ascorbic acid), characterized by the presence of open circular structures with some supercoiling. Clearly, the incubation of the biomolecule with complexes 1-3 affects significantly its structure (Fig. 9b-d, respectively). For 1, without the reducing agent, some linear, cleaved DNA is observed together with open circular structures (Fig. 9b, left). When the reducing

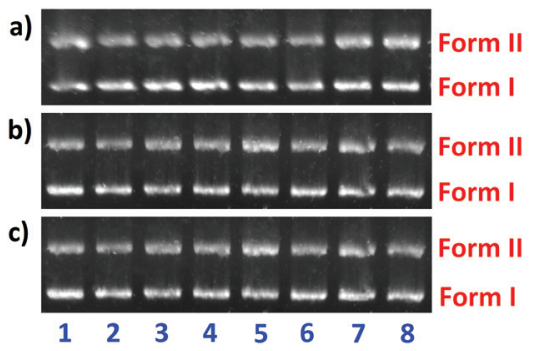

Fig. 8 Agarose gel electrophoresis images of pBR322 plasmid DNA (15 $\mu \mathrm{M}$ b.p.) incubated for $1 \mathrm{~h}$ at $37^{\circ} \mathrm{C}$ with increasing concentrations of the free ligand (a) Cltpy, (b) Naphtpy and (c) Bimztpy, without a reducing agent. Lane 1: pure plasmid DNA; lane 2: [free ligand] $=5 \mu \mathrm{M}$; lane 3: [free ligand] = $10 \mu \mathrm{M}$; lane 4: [free ligand] = $20 \mu \mathrm{M}$; lane 5: [free ligand] $=40 \mu \mathrm{M}$; lane 6: [free ligand] $=60 \mu \mathrm{M}$; lane 7: [free ligand] $=80 \mu \mathrm{M}$; lane 8: [free ligand] $=100 \mu \mathrm{M}$. The same results are observed in the presence of ascorbic acid (reducing agent).

a)

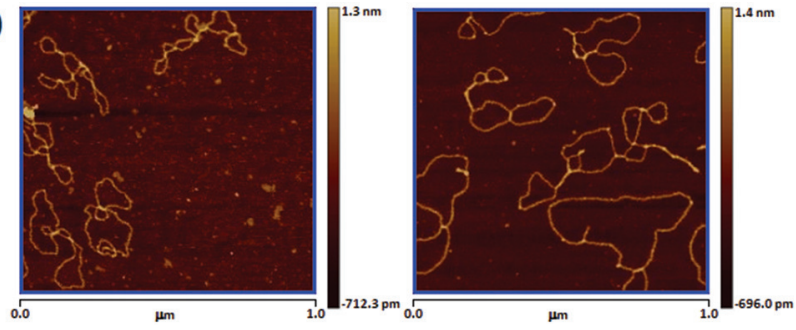

b)

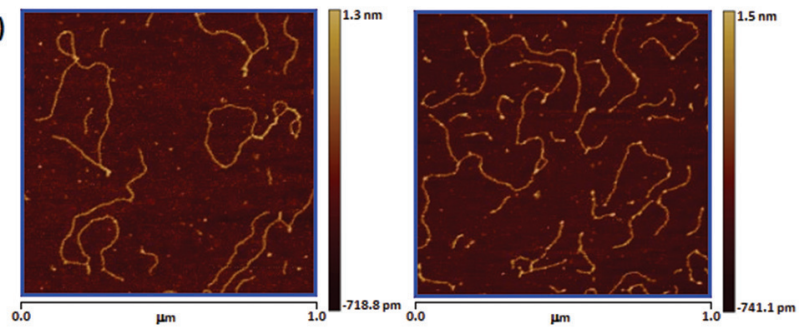

c)
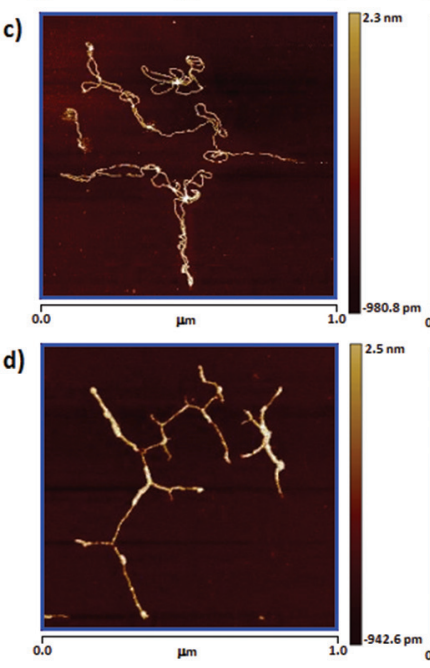

without reducing agent

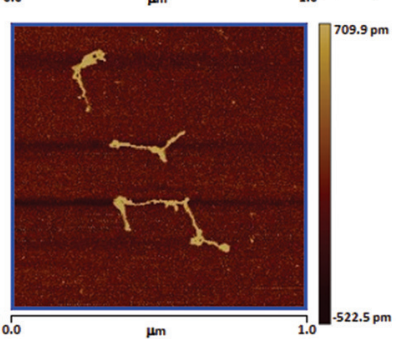

Fig. 9 AFM images of (a) pure pBR322 plasmid DNA (without and with ascorbic acid); (b-d) pBR322 plasmid DNA in the presence of complexes 1-3, respectively (left: without ascorbic acid; right: with ascorbic acid). [DNA] = $15 \mu \mathrm{M}$ b.p.; [complex] $=5 \mu \mathrm{M}$. 
agent is added, only linear forms are noticed, corroborating the DNA-cleaving properties of $\mathbf{1}$ observed by gel electrophoresis (see above). As already revealed by the electrophoretic results and the spectroscopic studies, complex 2 exhibits a drastically distinct behaviour. Indeed, with or without the reducing agent (Fig. 9c), 2 induces the formation of supercoiled forms with some globular aggregates (Fig. 9c right), which is indicative of a high affinity of the compound for DNA. No linearized forms are detected (even with the reducing agent; Fig. 9c right), which confirms that the interaction of 2 with DNA does not result in its cleavage. Finally, 3 without the reducing agent displays DNA-interacting properties, which are reflected by the formation of supercoiled forms (Fig. 9d, left). This feature suggests that 3 can bind to DNA thanks to its aromatic benzimidazole substituent (actually the $K_{\mathrm{b}}$ and $K_{\mathrm{Sv}}$ values for $\mathbf{3}$ are higher than those for $\mathbf{1}$, which does not induce supercoiling; see above). In the presence of a reducing agent, 3 cleaves the DNA efficiently (only linear forms are detected; Fig. 9d right), confirming the electrophoretic results (see above). In summary, as for the gel electrophoresis, the AFM studies show that $\mathbf{1}$ and $\mathbf{3}$ act as DNA cleavers, in contrast to 2 .

\section{ROS generation}

The production of ROS mediated by complexes 1-3 was first evaluated using ascorbic acid (AA); in the presence of ascorbate and dioxygen, $\mathrm{Cu}^{2+}$ will indeed generate ROS. ${ }^{63}$ The reactions were followed by measuring the AA consumption through its absorbance at $265 \mathrm{~nm}(\mathrm{pH} 7.4$, see the Experimental section), ${ }^{64}$ and the corresponding results are depicted in Fig. 10a. Without any copper catalyst (blank experiment), a very slight decrease in absorbance is observed (Fig. 10a). In contrast, in the presence of copper(II) ions (i.e. $\mathrm{CuCl}_{2}$ ), a rapid consumption of AA takes place, which is total after ca. 10 minutes. Compound $\mathbf{1}$ also generates a great amount of ROS, but less than $\mathrm{CuCl}_{2}$. Finally, compounds 2 and 3 exhibit similar behaviour, viz. both complexes are capable of producing ROS, but this production is clearly inferior compared to that mediated by $\mathrm{CuCl}_{2}$ and 1 (Fig. 10a). It can be noticed that 2 appears to generate slightly more ROS than 3 , which again suggests that the ROS-generation abilities of $\mathbf{2}$ are not operative upon binding to DNA (see above). Furthermore, the results achieved with $\mathbf{1}$ confirm that it is the most efficient ROS generator, which results in significant DNA cleavage.

Next, the potential formation of hydroxyl radicals was investigated with a highly specific fluorescent probe, namely coumarin-3-carboxylic acid (CCA). ${ }^{65,66}$ The metal-mediated formation of 7-hydroxy-coumarin-3-carboxylic acid (7-OH-CCA), through the reaction of CCA with $\mathrm{HO}^{\circ}$ radicals, was followed by fluorescence spectroscopy at $\mathrm{pH}$ 7.4, using the excitation wavelength of 7-OH-CCA, i.e. $385 \mathrm{~nm}$, which emits at $500 \mathrm{~nm}$ (see the Experimental section). The resulting 7-OH-CCA emission versus time curves is shown in Fig. 10b. Without copper (blank experiment), a slight increase in 7-OH-CCA fluorescence is observed, whereas the production of 7-OH-CCA is drastically enhanced in the presence of $\mathrm{CuCl}_{2}$. Surprisingly, compound 1, which exhibits significant ROS-
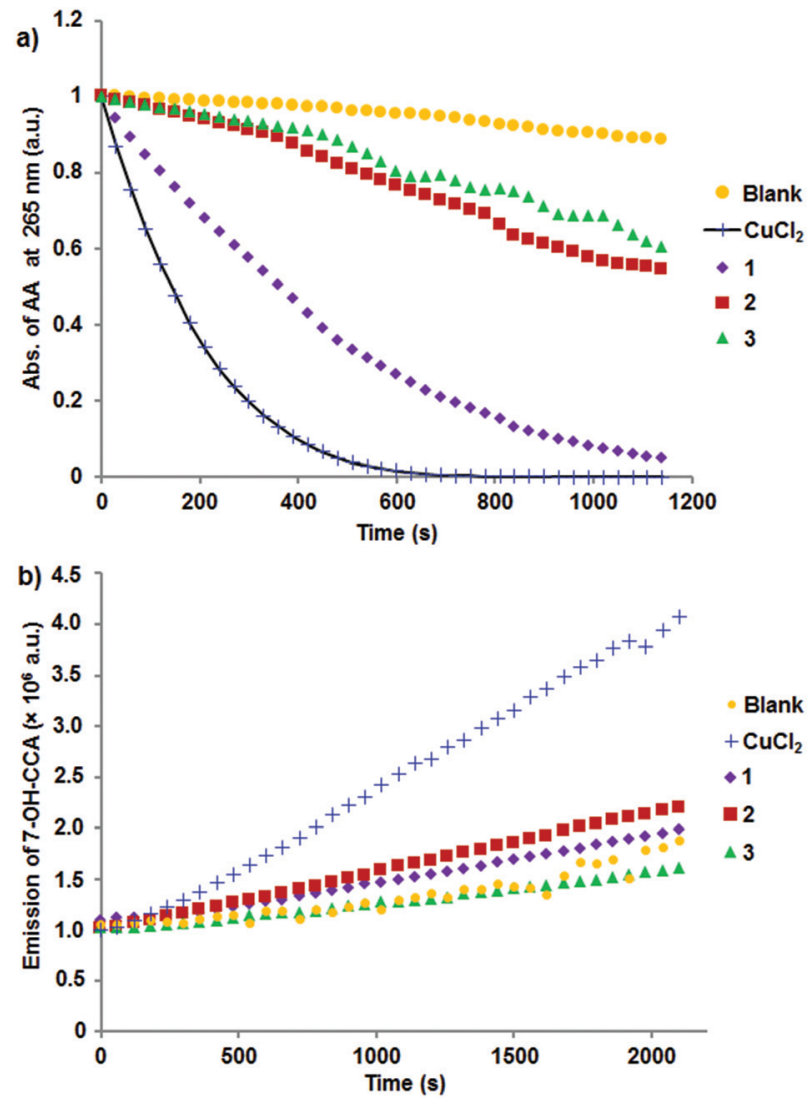

Fig. 10 (a) Consumption of ascorbic acid (AA) mediated by $\mathrm{CuCl}_{2}$ and complexes 1-3; $\left[\mathrm{CuCl}_{2}\right]=[$ complex $]=1 \mu \mathrm{M}$; $[\mathrm{AA}]=100 \mu \mathrm{M} ; 100 \mathrm{mM}$ phosphate buffer, pH 7.4. (b) Generation of 7-hydroxy-coumarin-3-carboxylic acid $\left(7-\mathrm{OH}-\mathrm{CCA} ; \lambda_{\text {exc }}=385 \mathrm{~nm}, \lambda_{\mathrm{em}}=500 \mathrm{~nm}\right)$ via metalmediated hydroxylation (HO') of coumarin-3-carboxylic acid (CCA); $\left[\mathrm{CuCl}_{2}\right]=[$ complex $]=10 \mu \mathrm{M} ;[\mathrm{AA}]=300 \mu \mathrm{M}$; [CCA $]=1 \mathrm{mM} ; 100 \mathrm{mM}$ phosphate buffer, $\mathrm{pH} 7.4$.

generating properties (see above; Fig. 10a), is not able to catalyse the formation of great amounts of 7-OH-CCA (Fig. 10b). This result may be explained by a reaction occurring at the ligand, the copper complex thus acting as a self-hydroxyl-radical scavenger. ${ }^{67,68}$ Compounds 2 and 3 also act as scavengers (particularly compound 3); however, some production of 7-OH-CCA is observed with 2 , which conversely does not cleave DNA (contrary to 1 and 3 ).

In summary, these experiments suggest that the strong DNA-binding affinity of 2 overrides its DNA-cleaving properties (as already indicated by the electrophoretic and AFM studies).

\section{Cytotoxicity assays}

Cell-viability assays were carried out with the free ligands Cltpy, Naphtpy and Bimztpy and complexes 1-3. In the first instance, each compound was screened by means of singlepoint assays, using two different concentrations, namely 10 and $50 \mu \mathrm{M}$, in six cancer cell lines, i.e. A549 (lung adenocarcinoma), A375 (melanoma), MCF-7 (breast adenocarcinoma), PC3 (prostate adenocarcinoma), SKOV3 (ovary 
adenocarcinoma) and SW620 (colorectal adenocarcinoma). The corresponding results obtained after an incubation time of 24 hours are shown in Fig. S7 and Table S4 $\uparrow$ for [compound] $=10 \mu \mathrm{M}$, and in Fig. 11 and Table 3 for [compound] $=50 \mu \mathrm{M}$. At a compound concentration of $10 \mu \mathrm{M}$, only complex 2 is capable of affecting cell viability with more than $50 \%$ of cell death in MCF-7 (breast adenocarcinoma), after an incubation time of 24 hours (see Table $\mathrm{S} 4 \dagger$ ). At higher [compound], namely $50 \mu \mathrm{M}$, the cytotoxic behavior of complex 2 is confirmed, since it shows good efficiencies for almost all cell lines tested (Fig. 11 and Table 3); for instance, only 5\% of the MCF-7 cells are still viable after an incubation time of 24 hours (Table 3). It is really interesting to note that complex 2 exhibits the best cytotoxicity properties. Indeed, from the gelelectrophoretic results (see above), one may have expected that complexes 1 and 3 would show better cytotoxicity properties than $\mathbf{2}$, since $\mathbf{1}$ and $\mathbf{3}$ act as DNA cleavers, in contrast to 2 . Therefore, it appears that the stronger DNA-binding behavior presented by $\mathbf{2}$ (in comparison with that of $\mathbf{1}$ and 3; see UV-vis and fluorescence spectroscopic studies) may be linked to its higher cytotoxic properties.

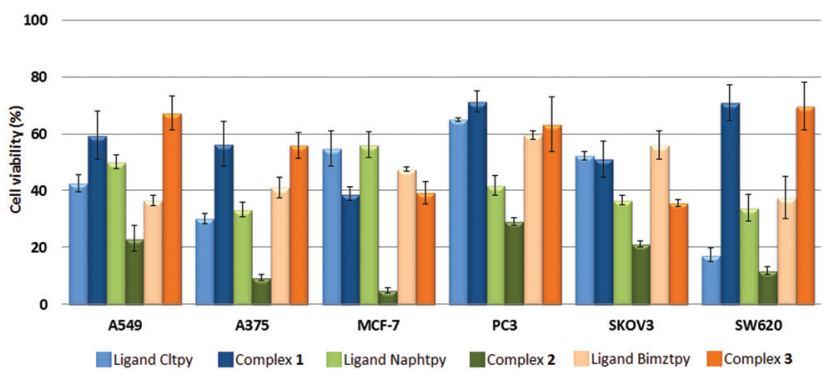

Fig. 11 Cell-viability assays (single-point screening, \% of cell viability) of the free ligands Cltpy, Naphtpy and Bimztpy and complexes 1-3 with different cancer cell lines, namely A549 (lung adenocarcinoma), A375 (melanoma), MCF-7 (breast adenocarcinoma), PC3 (prostate adenocarcinoma), SKOV3 (ovary adenocarcinoma) and SW620 (colorectal adenocarcinoma), using [compound] $=50 \mu \mathrm{M}$ and an incubation time of $24 \mathrm{~h}$. The results are means \pm SD of three separate experiments.
It can also be noticed that the free ligand Cltpy shows good cytotoxicity activity towards colon-cancer SW620 cells, with a cell viability of $17 \%$, after one-day incubation time (Fig. 11 and Table 3). Similar experiments have also been performed applying an incubation time of 48 hours (see Fig. S8 and Table S5†). After two days of incubation and [compound] $=10 \mu \mathrm{M}$, good cytotoxicity (cell-viability values below 40\%; Fig. S8A $\dagger$ ) is observed for all compounds in the skin-cancer A375 cell line. Furthermore, complexes 1-3 show substantial cytotoxicity against breast-cancer MCF-7 cells, with cell-viability values in the range $24-29 \%$ (Table $55 \dagger$ ). At a compound concentration of $50 \mu \mathrm{M}$ and incubation time of 48 hours, complex 2 is able to decrease the viability of almost all the types of cancer cells tested in the present study (Fig. S8B $\dagger$ ); in particular, the skin-, breast- and colon-cancer cells are completely eradicated (Table $55 \dagger$ ), and low cell-viability values are observed for the other cancer-cell lines (Table S5†). Complex 1 exhibits good cytotoxicity for three cell lines, namely lung A549, breast MCF-7 and ovary SKOV3 (Table S5 $\dagger$ ). Finally, complex 3 is active against breast MCF-7 and colon SW620 cells (Table S5 $\dagger$ ). Regarding the free ligands, it appears that the colon-cancer cells SW620 are the most sensitive to them (Table S5 $\dagger$ ).

Since all three complexes display notable cytotoxicity properties towards breast MCF-7 cancer cells, half maximal inhibitory concentration $\left(\mathrm{IC}_{50}\right)$ values for all compounds have been determined for this cell line. The corresponding results, after an incubation time of 24 hours, are shown in Fig. 12, and listed in Table 4 . For comparison purposes, $\mathrm{IC}_{50}$ values have also been obtained for cisplatin, the reference coordination compound used clinically, ${ }^{2}$ and the copper/phenanthroline complex $\left(\left[\mathrm{Cu}(\text { phen })_{2}\right] \mathrm{X}_{2} ; \mathrm{X}=\mathrm{NO}_{3}\right)^{69}$ which is the reference molecule for copper-based systems ${ }^{35}$ (Table 4). As expected, from all compounds reported herein, complex 2 presents the best $\mathrm{IC}_{50}$ value, i.e. $12 \mu \mathrm{M}$, which is much lower than that of cisplatin (that is $65 \mu \mathrm{M}$; Table 4). The reference copper/ phenanthroline complex, which is a DNA-cleaving agent ${ }^{35}$ (contrary to 2), exhibits the best cytotoxicity properties, as reflected by its $\mathrm{IC}_{50}$ value of $3.9 \mu \mathrm{M}$ (Table 4 ). However, it should be noticed that complex 2, like complex 3, Naphtpy and Bimztpy, gives a lower $\mathrm{IC}_{25}$ value than $\left[\mathrm{Cu}(\text { phen })_{2}\right]^{2+}$ (Table 4). Finally,

Table 3 Cell-viability assays (single-point screening, \% cell viability) of the free ligands and the copper complexes 1-3 in different cancer-cell lines, i.e. A549 (lung adenocarcinoma), A375 (melanoma), MCF-7 (breast adenocarcinoma), PC3 (prostate adenocarcinoma), SKOV3 (ovary adenocarcinoma) and SW620 (colorectal adenocarcinoma), using a pre-set [compound] of $50 \mu \mathrm{M}$ (single-point assay) and an incubation time of $24 \mathrm{~h}$. The data shown are means \pm SD of three independent experiments ${ }^{a}$

\begin{tabular}{|c|c|c|c|c|c|c|}
\hline \multirow[b]{2}{*}{ Compound } & \multicolumn{6}{|l|}{ Cell line } \\
\hline & A549 & A375 & MCF-7 & PC3 & SKOV3 & SW620 \\
\hline 1 & $60 \pm 8.4$ & $56 \pm 7.9$ & $39 \pm 2.3$ & $71 \pm 3.7$ & $51 \pm 6.4$ & $71 \pm 6.1$ \\
\hline Naphtpy & $50 \pm 2.5$ & $33 \pm 2.7$ & $56 \pm 4.5$ & $42 \pm 3.5$ & $37 \pm 1.6$ & $34 \pm 4.7$ \\
\hline 2 & $23 \pm 4.6$ & $9 \pm 1.1$ & $5 \pm 0.9$ & $29 \pm 1.3$ & $21 \pm 1.0$ & $12 \pm 1.4$ \\
\hline Bimztpy & $37 \pm 1.8$ & $41 \pm 3.6$ & $48 \pm 0.7$ & $60 \pm 1.5$ & $56 \pm 5.0$ & $38 \pm 7.5$ \\
\hline
\end{tabular}

${ }^{a}$ Cell viabilities $\leq 25 \%$ are shown in bold. 


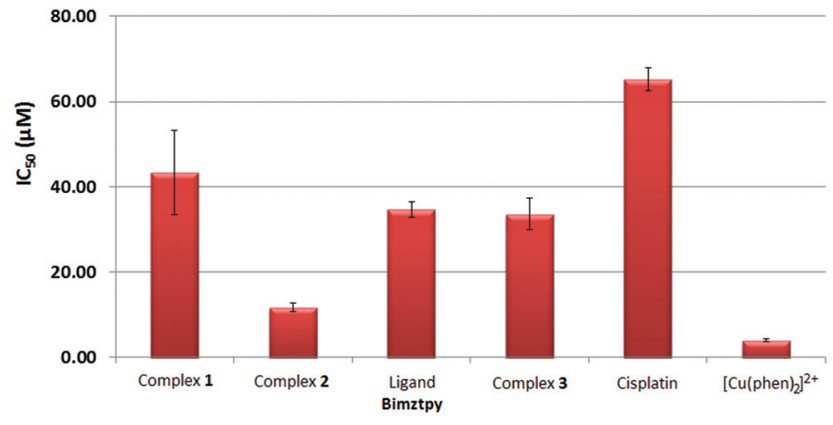

Fig. $12 \quad I_{50}$ values $(\mu \mathrm{M})$ from the dose-response assay of the ligand Bimztpy, the complexes 1-3 and the reference compounds cisplatin and $\left[\mathrm{Cu}\left(\mathrm{H}_{2} \mathrm{O}\right)(1,10 \text {-phenanthroline })_{2}\right]\left(\mathrm{NO}_{3}\right)_{2}{ }^{69}$ (symbolized as $\left[\mathrm{Cu}(\text { phen })_{2}\right]^{2+}$ ) in the MCF-7 cell line, after an incubation time of 24 hours (see Table 4). The results shown are means \pm SD of triplicate experiments.

Table $4 \quad I_{25}, I C_{50}$ and $I C_{75}$ values $(\mu \mathrm{M})$ of the free ligands Cltpy, Naphtpy and Bimztpy and complexes 1-3 for the MCF-7 cell line (breast adenocarcinoma), after $24 \mathrm{~h}$ incubation \pm SD of three independent experiments

\begin{tabular}{lcll}
\hline Compound & $\mathrm{IC}_{25}$ & $\mathrm{IC}_{50} a, b$ & $\mathrm{IC}_{75}{ }^{a}$ \\
\hline Cltpy & $11 \pm 1.3$ & N.D. & N.D. \\
$\mathbf{1}$ & $3.4 \pm 0.40$ & $43 \pm 9.9$ & N.D. \\
Naphtpy & $1.2 \pm 0.17$ & N.D. & N.D. \\
$\mathbf{2}$ & $1.33 \pm 0.19$ & $\mathbf{1 2} \pm \mathbf{0 . 9 7}$ & $22 \pm 3.7$ \\
Bimztpy & $1.65 \pm 0.63$ & $35 \pm 1.8$ & N.D. \\
$\mathbf{3}$ & $2.2 \pm 0.12$ & $34 \pm 3.7$ & $70 \pm 1.7$ \\
Cisplatin & $35 \pm 3.8$ & $65 \pm 2.8$ & N.D. \\
$\left.[\text { Cu(phen })_{2}\right]^{2+}$ & $2.6 \pm 0.68$ & $\mathbf{3 . 9} \pm \mathbf{0 . 3 5}$ & $8.6 \pm 3.7$
\end{tabular}

${ }^{a}$ N.D. $=$ not determined. ${ }^{b}$ The lowest $\mathrm{IC}_{50}$ values are shown in bold.

determination of the $\mathrm{IC}_{75}$ values reveals that besides complex 2 , complex 3 shows some activity (although much lower than the DNA cleaver $\left.\left[\mathrm{Cu}(\text { phen })_{2}\right]^{2+}\right)$.

\section{Conclusions}

In the present study, three terpyridine-based ligands, bearing different $\mathrm{R}$ groups at position $4^{\prime}(\mathrm{R}=\mathrm{Cl}$, naphthyl or benzimidazole), have been used to generate copper(II) complexes, with the objective to examine the role played by distinct types of supramolecular interactions on their DNA-interacting and cytotoxic properties. Interestingly, the results obtained show that the most efficient metal complex is 2, which contains the naphthyl group and exhibits the best DNA-interacting properties. Unexpectedly, complexes 1 and 3, which are capable of cleaving the DNA strands (whereas 2 cannot), are significantly less cytotoxic than 2 (at least in the cell lines tested). Therefore, a coordination compound displaying DNA-cleaving abilities will not necessarily exhibit greater cytotoxicity behaviour than a related complex which does not act as a DNA cleaver. The strong DNA-interacting properties of the naphthyl group (through supramolecular $\pi-\pi$ interactions) of 2 appear to be a critical issue regarding its biological activity.

Subsequent studies will be dedicated to investigate the influence of larger aryl substituents (e.g. anthracenyl, pyrenyl) and of spacers of different lengths between the aryl group and the terpy moiety on the biological properties of new copper(II) complexes derived from 2 .

\section{Experimental section}

\section{General methods}

All reactions were performed under aerobic conditions and all reagents and solvents were purchased from Sigma-Aldrich or Acros Organics. The reference copper(II)-phenanthroline complex $\left[\mathrm{Cu}\left(\mathrm{H}_{2} \mathrm{O}\right)(1,10 \text {-phenanthroline })_{2}\right]\left(\mathrm{NO}_{3}\right)_{2}$ was prepared following the procedure described by K. J. Catalan et al. ${ }^{69}$ pBR322 plasmid DNA was purchased from Roche and calf thymus DNA was obtained from Sigma-Aldrich. ${ }^{1} \mathrm{H},{ }^{13} \mathrm{C}\left\{{ }^{1} \mathrm{H}\right\}$ and heteronuclear $\left\{{ }^{1} \mathrm{H}_{-}{ }^{13} \mathrm{C}\right\}$-HSQC NMR spectra were recorded at room temperature with a Varian Unity $400 \mathrm{MHz}$ spectrometer. Proton and carbon chemical shifts are expressed in parts per million ( $\mathrm{ppm}, \delta$ scale) and are referenced to the peak of the solvent used. Infrared spectra (as $\mathrm{KBr}$ pellets) were recorded using a Nicolet-5700 FT-IR (in the range 4000-400 $\mathrm{cm}^{-1}$ ), and data are represented as the frequency of absorption $\left(\mathrm{cm}^{-1}\right)$. Elemental analyses were performed by the Servei de Microanalisi, Serveis Cientificotècnics of the University of Barcelona. UV-Vis experiments were performed with a Varian Cary-100 spectrophotometer. The fluorescence measurements were carried out with a KONTRON SFM 25 spectrofluorometer. ESI mass spectroscopy was carried out using a LC/MSD-TOF Spectrometer from Agilent Technologies, equipped with an electrospray ionization (ESI) source at the Serveis Cientificotècnics of the University of Barcelona.

\section{Preparation of the ligands naphtpy and bimztpy}

The ligands were synthesized by reaction of 2-naphthalenemethanol or benzimidazol-2-methanol with $4^{\prime}$-chloro-2,2':6',2"terpyridine (Cltpy) in DMSO in the presence of potassium hydroxide, following a known procedure. ${ }^{48}$

Synthesis of $4^{\prime}$-((naphthalen-2-yl)methoxy)-2,2':6',2"-terpyridine (naphtpy). $0.100 \mathrm{~g}(0.632 \mathrm{mmol})$ of 2-naphthalenemethanol was added to a suspension of $\mathrm{KOH}(0.039 \mathrm{~g} ; 0.700 \mathrm{mmol})$ in $15 \mathrm{~mL}$ of dry DMSO. After stirring for 30 minutes at $70{ }^{\circ} \mathrm{C}$, $0.165 \mathrm{~g}(0.620 \mathrm{mmol})$ of Cltpy was added, and the resulting reaction mixture was further stirred for 4 hours at $70^{\circ} \mathrm{C}$. Subsequently, this reaction mixture was poured into $150 \mathrm{~mL}$ of ice water. The white precipitate formed was filtered off, washed with cold water and chloroform $(3 \times 5 \mathrm{~mL})$, and dried under reduced pressure. Yield $=0.199 \mathrm{~g}(0.512 \mathrm{mmol}, 81 \%)$. Anal. calcd for [naphtpy + 0.35 DMSO], $\mathrm{C}_{26.7} \mathrm{H}_{21.1} \mathrm{~N}_{3} \mathrm{SO}_{1.35}$ : C, 77.10; H, 4.89; N, 9.76. Found: C. 76.94; H, 5.10; N, 10.08. ESI-MS: $m / z=390.23[\mathrm{M}+\mathrm{H}]^{+}, 141.07[(2-m e t h y l) n a p h t h a l e n e-\mathrm{H}]^{+}$. ${ }^{1} \mathrm{H}$ NMR (400 MHz, d $\mathrm{d}_{6}$-DMSO): $\delta(\mathrm{ppm})=8.72(\mathrm{~d}, 2 \mathrm{H}, J=$ $\left.4.0 \mathrm{~Hz}, \mathrm{H}_{\mathrm{a}}\right), 8.62\left(\mathrm{~d}, 2 \mathrm{H}, J=8.0 \mathrm{~Hz}, \mathrm{H}_{\mathrm{d}}\right), 8.12\left(\mathrm{~s}, 2 \mathrm{H}, \mathrm{H}_{\mathrm{e}}\right), 8.08$ 
$\left(\mathrm{s}, 1 \mathrm{H}, \mathrm{H}_{\mathrm{f}}\right), 8.01\left(\mathrm{~m}, 2 \mathrm{H}, \mathrm{H}_{\mathrm{c}}\right), 7.99\left(\mathrm{~m}, 1 \mathrm{H}, \mathrm{H}_{\mathrm{h}}\right), 7.96(\mathrm{~m}, 1 \mathrm{H}$, $\left.\mathrm{H}_{\mathrm{g}}\right), 7.67\left(\mathrm{~d}, 2 \mathrm{H}, J=4.0 \mathrm{~Hz}, \mathrm{H}_{\mathrm{i}}\right), 7.54\left(\mathrm{~m}, 2 \mathrm{H}, \mathrm{H}_{\mathrm{b}}\right), 7.49(\mathrm{~m}, 2 \mathrm{H}$, $\left.\mathrm{H}_{\mathrm{j}}\right), 5.58\left(\mathrm{~s}, 2 \mathrm{H}, \mathrm{H}_{\mathrm{k}}\right) \cdot{ }^{13} \mathrm{C} \mathrm{NMR}\left(400 \mathrm{MHz}, \mathrm{d}_{6}-\mathrm{DMSO}\right): \delta(\mathrm{ppm})=$ $166.2\left(\mathrm{C}_{\mathrm{e}^{\prime \prime}}\right), 156.8\left(\mathrm{C}_{\mathrm{e}^{\prime}}\right), 154.8\left(\mathrm{C}_{\mathrm{d}^{\prime}}\right), 149.3\left(\mathrm{C}_{\mathrm{a}}\right), 137.4\left(\mathrm{C}_{\mathrm{c}}\right)$, $133.9\left(\mathrm{C}_{\mathrm{k}^{\prime}}\right), 132.8\left(\mathrm{C}_{\mathrm{f}^{\prime}}\right), 132.6\left(\mathrm{C}_{\mathrm{h}^{\prime}}\right), 128.1\left(\mathrm{C}_{\mathrm{h}}\right), 127.9\left(\mathrm{C}_{\mathrm{g}}\right), 126.4$ $\left(\mathrm{C}_{\mathrm{f}}\right), 126.2\left(\mathrm{C}_{\mathrm{b}}\right), 125.5\left(\mathrm{C}_{\mathrm{i}}\right), 124.6\left(\mathrm{C}_{\mathrm{j}}\right), 120.9\left(\mathrm{C}_{\mathrm{d}}\right), 107.2\left(\mathrm{C}_{\mathrm{e}}\right)$, $69.6\left(\mathrm{C}_{\mathrm{k}}\right)$. IR (KBr): $\nu=3426,1583,1561,1404,1196,1022$, $796 \mathrm{~cm}^{-1}$.

Synthesis of $4^{\prime}-((1 H$-benzo[d]imidazol-2-yl)methoxy)-2,2':6',2"terpyridine (bimztpy). $0.250 \mathrm{~g}(1.67 \mathrm{mmol})$ of benzimidazol-2methanol was added to a suspension of $\mathrm{KOH}(0.470 \mathrm{~g}$; $8.38 \mathrm{mmol}$ ) in $12 \mathrm{~mL}$ of dry DMSO. After stirring for 30 minutes at $70{ }^{\circ} \mathrm{C}, 0.452 \mathrm{~g}(1.68 \mathrm{mmol})$ of Cltpy was added, and the resulting reaction mixture was further stirred for 4 hours at $70{ }^{\circ} \mathrm{C}$. Subsequently, this reaction mixture was poured into $150 \mathrm{~mL}$ of ice water. The white precipitate formed was filtered off, washed with cold water and dried. Yield = $0.259 \mathrm{~g}(0.68 \mathrm{mmol}, 41 \%)$. Anal. calcd for [bimztpy $+2 \mathrm{H}_{2} \mathrm{O}$ ], $\mathrm{C}_{23} \mathrm{H}_{21} \mathrm{~N}_{5} \mathrm{O}_{3}$ : C, 66.50; H, 5.09; N, 16.85. Found: C, 65.52; $\mathrm{H}, 5.23$; N, 16.99. ESI-MS: $m / z=781.28[2 \mathrm{M}+\mathrm{Na}]^{+}, 402.13$ $[\mathrm{M}+\mathrm{Na}]^{+}, 380.15[\mathrm{M}+\mathrm{H}]^{+} .{ }^{1} \mathrm{H}$ NMR (400 MHz, d $\mathrm{d}_{6}$-DMSO): $\delta(\mathrm{ppm})=8.73\left(\mathrm{~d}, 2 \mathrm{H}, J=4.3 \mathrm{~Hz}, \mathrm{H}_{\mathrm{a}}\right), 8.62(\mathrm{~d}, 2 \mathrm{H}, J=7.9 \mathrm{~Hz}$, $\left.\mathrm{H}_{\mathrm{d}}\right), 8.14\left(\mathrm{~s}, 2 \mathrm{H}, \mathrm{H}_{\mathrm{e}}\right), 8.01\left(\mathrm{dd}, 2 \mathrm{H}, J=7.7 \mathrm{~Hz}, \mathrm{H}_{\mathrm{c}}\right), 7.57(\mathrm{~m}, 2 \mathrm{H}$, $\left.\mathrm{H}_{\mathrm{f}}\right), 7.51\left(\mathrm{dd}, 2 \mathrm{H}, J=4.3 \mathrm{~Hz}\right.$ and $\left.J=7.7 \mathrm{~Hz}, \mathrm{H}_{\mathrm{b}}\right), 7.20(\mathrm{dd}, 2 \mathrm{H}$, $J=5.9 \mathrm{~Hz}$ and $\left.J=3.1 \mathrm{~Hz}, \mathrm{H}_{\mathrm{g}}\right), 5.64\left(\mathrm{~s}, 2 \mathrm{H}, \mathrm{H}_{\mathrm{k}}\right) \cdot{ }^{13} \mathrm{C} \mathrm{NMR}$ $\left(400 \mathrm{MHz}, \mathrm{d}_{6}\right.$-DMSO): $\delta(\mathrm{ppm})=166.3\left(\mathrm{C}_{\mathrm{e}^{\prime \prime}}\right), 157.0\left(\mathrm{C}_{\mathrm{e}^{\prime}}\right)$, $154.9\left(\mathrm{C}_{\mathrm{d}^{\prime}}\right), 149.6\left(\mathrm{C}_{\mathrm{k}^{\prime}}\right), 149.5\left(\mathrm{C}_{\mathrm{a}}\right), 137.7\left(\mathrm{C}_{\mathrm{f}^{\prime}}\right), 137.6\left(\mathrm{C}_{\mathrm{c}}\right)$, $124.8\left(\mathrm{C}_{\mathrm{b}}\right), 124.8\left(\mathrm{C}_{\mathrm{f}}\right), 122.3\left(\mathrm{C}_{\mathrm{g}}\right), 121.3\left(\mathrm{C}_{\mathrm{d}}\right), 107.4\left(\mathrm{C}_{\mathrm{e}}\right)$, $64.2\left(\mathrm{C}_{\mathrm{k}}\right)$. IR (KBr): $\nu=3187,1583,1565,1348,739 \mathrm{~cm}^{-1}$.

\section{Preparation of the copper(II) complexes}

$0.41 \mathrm{mmol}$ of the ligand were suspended in $40 \mathrm{~mL}$ of methanol and heated at $50{ }^{\circ} \mathrm{C}$ until complete dissolution. To this solution, $0.100 \mathrm{~g}(0.41 \mathrm{mmol})$ of copper(II) nitrate trihydrate in $10 \mathrm{~mL}$ of methanol were added. The resulting mixture was stirred at $40{ }^{\circ} \mathrm{C}$ for 2 hours and then left for the slow evaporation of the solvent. After a few days, a precipitate or crystals appeared, which was filtered off, washed with ethyl ether and dried under reduced pressure.

[Cu(Cltpy)( $\left.\left.\mathbf{H}_{2} \mathbf{O}\right)\left(\mathrm{NO}_{3}\right)_{2}\right]$ (1). Yield: $98 \mathrm{mg}$ [51\%]. Anal. calcd for $\mathrm{C}_{15} \mathrm{H}_{12} \mathrm{ClCuN}_{5} \mathrm{O}_{7}$ (\%): C, 38.07; H, 2.56; N, 14.80. Found: $\mathrm{C}, 37.94 ; \mathrm{H}, 2.61, \mathrm{~N}, 14.77$. IR (KBr): $\nu=3414,3098,1585$, 1561, 1445, 1416, 1404, 1274, 1112, 1017, $802 \mathrm{~cm}^{-1}$.

$\left[\mathbf{C u}\left(\mathbf{H}_{2} \mathbf{O}\right)\left(\right.\right.$ naphtpy) $\left.\left(\mathbf{N O}_{3}\right)\right]\left(\mathbf{N O}_{3}\right)$ (2). Yield: $192 \mathrm{mg}[79 \%]$. Anal. calcd for $\mathrm{C}_{26} \mathrm{H}_{21} \mathrm{CuN}_{5} \mathrm{O}_{8}$ (\%): C, 52.48; H, 3.56; N, 11.77. Found: C, 52.46; H, 3.19, N, 11.79. IR (KBr): $\nu=3493$, 3061, 1617, 1474, 1383, $1222 \mathrm{~cm}^{-1}$.

$\left[\mathrm{Cu}\left(\right.\right.$ bimztpy)( $\left.\left.\mathbf{H}_{2} \mathbf{O}\right)\left(\mathrm{NO}_{3}\right)\right]\left(\mathrm{NO}_{3}\right)$ (3). Yield: $204 \mathrm{mg} \quad[81 \%]$. Anal. calcd for $\left\{\left[\mathrm{Cu}(\right.\right.$ bimztpy $\left.\left.)\left(\mathrm{H}_{2} \mathrm{O}\right)\left(\mathrm{NO}_{3}\right)\right]\left(\mathrm{NO}_{3}\right)+1.5 \mathrm{H}_{2} \mathrm{O}\right\}$ $\mathrm{C}_{23} \mathrm{H}_{23} \mathrm{CuN}_{7} \mathrm{O}_{9.5}$ (\%): C, 45.06; H, 3.78; N, 15.99. Found: C, 45.11; H, 3.10, N, 15.88. IR (KBr): $\nu=3422,3074,1617$, $1478,1383,1217 \mathrm{~cm}^{-1}$.

\section{X-ray crystallography}

Data for the ligand Naphtpy were collected on a colourless plate of dimensions $0.28 \times 0.08 \times 0.02 \mathrm{~mm}^{3}$ at $100 \mathrm{~K}$ using a
Bruker APEX II QUAZAR diffractometer equipped with a microfocus multilayer monochromator with Mo K $\alpha$ radiation $(\lambda=0.71073 \AA)$. Data for compounds 1 and 2 were obtained respectively at 100 and $150 \mathrm{~K}$, on a blue plate of dimensions $0.45 \times 0.08 \times 0.04 \mathrm{~mm}^{3}(\mathbf{1})$, and on a green needle of dimensions $0.40 \times 0.04 \times 0.02 \mathrm{~mm}^{3}$ on a Bruker D8 diffractometer using the Advanced Light Source beam-line 11.3.1 at Lawrence Berkeley National Laboratory, from a silicon 111 monochromator $(\lambda=0.7749 \AA)$. Data reduction and absorption corrections were performed with SAINT and SADABS, respectively. ${ }^{70}$ The structures were solved and refined on $F^{2}$ with the SHELXTL suite. ${ }^{70,71}$ Non-hydrogen atoms were refined with anisotropic thermal parameters while hydrogen atoms were included at calculated positions and refined with isotropic thermal parameters, except those on the water molecules on the structures of $\mathbf{1}$ and 2, which were found in difference Fourier maps and refined freely with their isotropic thermal parameter 1.5 times that of their carrier oxygen.

\section{Gel electrophoresis}

Stock solutions of the copper(II) compounds were prepared in $40 \mathrm{mM}$ HEPES-10 mM $\mathrm{MgCl}_{2}$ buffer $(\mathrm{pH}=7.2) \cdot \operatorname{pBR} 322$ plasmid DNA aliquots $\left(0.2 \mathrm{mg} \mathrm{mL}^{-1}\right)$ in $40 \mathrm{mM}$ HEPES-10 $\mathrm{mM}$ $\mathrm{MgCl}_{2}$ buffer were incubated with the complexes for $1 \mathrm{~h}$ at $37^{\circ} \mathrm{C}$. Subsequently, ascorbic acid $(100 \mu \mathrm{M}$ in $40 \mathrm{mM}$ HEPES$10 \mathrm{mM} \mathrm{MgCl}$ buffer) was added (in the case of experiments without ascorbic acid, this step was skipped) and the resulting mixture $(15 \mu \mathrm{M}$ DNA b.p. in a $100 \mathrm{mM}$ solution of the complex) was incubated at $37^{\circ} \mathrm{C}$ for an additional hour. Next, the reaction samples were treated with $4 \mu \mathrm{L}$ of a quenching solution (30\% (v/v) glycerol; 0.25\% (w/v) bromophenol blue and $0.25 \%(\mathrm{w} / \mathrm{v})$ xylene cyanol), and then electrophoretized on agarose gel (1\% in TAE buffer, Tris-acetate-EDTA) for $2 \mathrm{~h}$ at 1.5 $\mathrm{V} \mathrm{cm}{ }^{-1}$, using a BIORAD horizontal tank connected to a PHARMACIA GPS 200/400 variable potential power supply. Samples of free DNA and DNA in the presence of ascorbic acid were used as controls. Afterwards, the DNA was stained with SYBR® safe and the gel was photographed with a BIORAD Gel Doc ${ }^{\mathrm{TM}}$ EZ Imager.

\section{AFM experiments}

pBR322 plasmid DNA was heated just before use at $60{ }^{\circ} \mathrm{C}$ for 10 min to obtain a homogeneous distribution of topoisomers. The stock solutions of the complexes and plasmid DNA, as well as the reaction samples (namely the DNA-complexascorbic acid mixtures), were prepared as above (see the Gel electrophoresis section). The AFM samples were prepared by casting a $5 \mu \mathrm{L}$ drop of test solution onto freshly cleaved muscovite green mica disks as the support. The drop was allowed to stand undisturbed for $3 \mathrm{~min}$ to favour the adsorbate-substrate interaction. Each DNA-laden disk was rinsed with Milli-Q water and was blown dry with clean compressed argon gas directed normal to the disk surface. The samples were stored over silica prior to AFM imaging. 


\section{ROS-generation studies}

Consumption of ascorbic acid (AA). First, a $100 \mathrm{mM}$ phosphate buffer solution ( $\mathrm{pH}$ 7.4) was prepared, which was treated with a Chelex® 100 resin (Bio-Rad) to remove any traces of metal ions. Next, a copper solution $\left(1 \mu \mathrm{M} \mathrm{CuCl}_{2}\right.$ or compounds 1-3) was added. The reaction was initiated through the addition of a solution of AA to a final concentration of $100 \mu \mathrm{M}$. The consumption of AA was followed by its UV absorbance at $265 \mathrm{~nm}$.

Formation of 7-hydroxy-coumarin-3-carboxylic acid (7-OH-CCA). A solution of the copper catalyst $\left(10 \mu \mathrm{M} \mathrm{CuCl}{ }_{2}\right.$ or compounds 1-3) was added to a $1 \mathrm{mM}$ solution of coumarin-3carboxylic acid (CCA) in $100 \mathrm{mM}$ phosphate buffer solution ( $\mathrm{pH}$ 7.4; previously treated with Chelex ${ }^{\circledR} 100$ resin). The reaction was initiated by the addition of a solution of AA to a final concentration of $300 \mu \mathrm{M}$. The generation of 7-OH-CCA was followed by fluorescence spectroscopy through its emission at $500 \mathrm{~nm}$, when excited at $385 \mathrm{~nm}$.

\section{Cell cultures}

Human melanoma (A375) and lung (A549), breast (MCF-7), prostate (PC3), ovary (SKOV3) and colorectal (SW620) adenocarcinoma cell lines were purchased from the American Type Culture Collection (ATCC, Manassas, VA, USA). The cell lines A549, A375, SKOV3 and SW620 were cultured in DMEM medium and PC3 in F12 medium. All media were supplemented with 10\% heat-inactivated fetal bovine serum (FBS; Life Technologies, Carlsbad, CA, USA), $100 \mathrm{U} \mathrm{mL}^{-1}$ penicillin, $100 \mu \mathrm{g} \mathrm{mL}^{-1}$ streptomycin, and $2 \mathrm{mM}$ L-glutamine. The MCF-7 cell line was cultured in DMEM-F12 (HAM) media (1:1) supplemented with $5 \%$ horse serum (Life Technologies), $100 \mu \mathrm{M}$ sodium pyruvate (Sigma-Aldrich Chemical Co., St. Louis, MO, USA), $10 \mu \mathrm{g} \mathrm{mL}^{-1}$ insulin (Sigma-Aldrich), $100 \mathrm{U} \mathrm{mL}^{-1}$ penicillin, $100 \mu \mathrm{g} \mathrm{mL} \mathrm{m}^{-1}$ streptomycin, and $2 \mathrm{mM}$ L-glutamine. The media and supplements whenever not stated were bought from Biological Industries, Beit Haemek, Israel. Cells were grown at $37^{\circ} \mathrm{C}$ under a $5 \% \mathrm{CO}_{2}$ atmosphere.

\section{Cell-viability assays}

Cells $\left(1 \times 10^{5}\right.$ cells per $\left.\mathrm{mL}\right)$ were seeded in 96-well plates and allowed to grow for $24 \mathrm{~h}$. For single-point experiments, the cells were treated with two different concentrations, i.e. $10 \mu \mathrm{M}$ and $50 \mu \mathrm{M}$, of the compounds investigated for 24 and $48 \mathrm{~h}$. For the dose-response curves, the cells were treated with different concentrations of the compounds; in the range $0.63-80 \mu \mathrm{M}$ for $24 \mathrm{~h}$. After treatment, a $10 \mu \mathrm{M}$ solution of MTT (3-(4,5-dimethylthiazol-2-yl)-2,5-diphenyl-tetrazolium bromide; Sigma-Aldrich) was added to each well and the plates were incubated at $37^{\circ} \mathrm{C}$ for another $4 \mathrm{~h}$. Subsequently, the medium was removed and the purple formazan crystals were dissolved in DMSO. Absorbance was measured at $570 \mathrm{~nm}$ using a multiwell plate reader (Multiskan FC, Thermo Scientific). The cell viability was calculated as follows: viability $(\%)=[($ absorbance of the treated wells)/(absorbance of the control wells) $] \times 100$. The $\mathrm{IC}_{50}$ values (which correspond to the compound concen- trations in $\mu \mathrm{M}$ that produce $50 \%$ cell-viability reduction) were obtained from the dose-response curves using GraphPad Prism V5.0 for windows (Graphpad Software, San Diego, CA, USA). All data are shown as the mean value \pm S.D. of three independent experiments for single-point assays and for the dose-response curves.

\section{Acknowledgements}

PG acknowledges ICREA (Institució Catalana de Recerca i Estudis Avançats) and the Ministerio de Economía y Competitividad (MINECO) of Spain (Projects CTQ2011-27929-C02-01 and CTQ2014-55293-P). This work was partially supported by a grant from the Spanish government and the EU (FIS PI13/00089), a grant from La Marató de TV3 Foundation (20132730) and the individual grant from Fundação para a Ciência e Tecnologia of the Portuguese Ministry of Science and Higher Education to LKG (SFRH/BPD/91766/2012). The European Union (EU) through COST Action CM1105 is kindly acknowledged.

\section{Notes and references}

1 B. Rosenberg, L. van Camp and T. Krigas, Nature, 1965, 205, 698-699.

2 J. Reedijk, Eur. J. Inorg. Chem., 2009, 1303-1312.

3 B. Rosenberg, L. van Camp, J. E. Trosko and V. H. Mansour, Nature, 1969, 222, 385-386.

4 F. Arnesano and G. Natile, Coord. Chem. Rev., 2009, 253, 2070-2081.

5 L. Kelland, Nat. Rev. Cancer, 2007, 7, 573-584.

6 M. Gordon and S. Hollander, J. Med., 1993, 24, 209-265.

7 Y. W. Jung and S. J. Lippard, Chem. Rev., 2007, 107, 13871407.

8 A. Gelasco and S. J. Lippard, Biochemistry, 1998, 37, 92309239.

9 P. M. Takahara, C. A. Frederick and S. J. Lippard, J. Am. Chem. Soc., 1996, 118, 12309-12321.

10 D. Z. Yang, S. S. G. E. van Boom, J. Reedijk, J. H. van Boom and A. H. J. Wang, Biochemistry, 1995, 34, 12912-12920.

11 S. E. Sherman, D. Gibson, A. H. J. Wang and S. J. Lippard, Science, 1985, 230, 412-417.

12 S. M. Cohen and S. J. Lippard, Prog. Nucleic Acid Res. Mol. Biol., 2001, 67, 93-130.

13 D. Wang and S. J. Lippard, Nat. Rev. Drug Discovery, 2005, 4, 307-320.

14 W. P. Roos and B. Kaina, Cancer Lett., 2013, 332, 237-248.

15 G. Giaccone, Drugs, 2000, 59, 9-17.

16 B. A. Chabner and T. G. Roberts, Nat. Rev. Cancer, 2005, 5, 65-72.

17 C. A. Rabik and M. E. Dolan, Cancer Treat. Rev., 2007, 33, 9-23.

18 M. A. Fuertes, C. Alonso and J. M. Perez, Chem. Rev., 2003, 103, 645-662.

19 R. P. Miller, R. K. Tadagavadi, G. Ramesh and W. B. Reeves, Toxins, 2010, 2, 2490-2518. 
20 F. E. de Jongh, R. N. van Veen, S. J. Veltman, R. de Wit, M. E. L. van der Burg, M. J. van den Bent, A. S. T. Planting, W. J. Graveland, G. Stoter and J. Verweij, Br. J. Cancer, 2003, 88, 1199-1206.

21 G. Momekov and D. Momekova, Expert Opin. Ther. Pat., 2006, 16, 1383-1403.

22 T. Boulikas and M. Vougiouka, Oncol. Rep., 2003, 10, 16631682.

23 N. P. E. Barry and P. J. Sadler, Chem. Commun., 2013, 49, 5106-5131.

24 S. H. van Rijt and P. J. Sadler, Drug Discovery Today, 2009, 14, 1089-1097.

25 U. Jungwirth, C. R. Kowol, B. K. Keppler, C. G. Hartinger, W. Berger and P. Heffeter, Antioxid. Redox Signaling, 2011, 15, 1085-1127.

26 D. S. Sigman, A. Mazumder and D. M. Perrin, Chem. Rev., 1993, 93, 2295-2316.

27 J. Y. Chen and J. Stubbe, Nat. Rev. Cancer, 2005, 5, 102-112.

28 U. Galm, M. H. Hager, S. G. Van Lanen, J. H. Ju, J. S. Thorson and B. Shen, Chem. Rev., 2005, 105, 739-758.

29 M. Pitie and G. Pratviel, Chem. Rev., 2010, 110, 1018-1059.

30 C. Santini, M. Pellei, V. Gandin, M. Porchia, F. Tisato and C. Marzano, Chem. Rev., 2014, 114, 815-862.

31 L. Ruiz-Azuara and M. E. Bravo-Gomez, Curr. Med. Chem., 2010, 17, 3606-3615.

32 R. P. Hertzberg and P. B. Dervan, J. Am. Chem. Soc., 1982, 104, 313-315.

33 M. W. Vandyke, R. P. Hertzberg and P. B. Dervan, Proc. Natl. Acad. Sci. U. S. A., 1982, 79, 5470-5474.

34 D. S. Sigman, D. R. Graham, V. Daurora and A. M. Stern, J. Biol. Chem., 1979, 254, 2269-2272.

35 R. F. Brissos, A. Caubet and P. Gamez, Eur. J. Inorg. Chem., 2015, 2633-2645.

36 U. S. Schubert, H. Hofmeier and G. R. Newkome, Modern Terpyridine Chemistry, Wiley-VCH, Weinheim, 2006.

37 A. Wild, A. Winter, F. Schlutter and U. S. Schubert, Chem. Soc. Rev., 2011, 40, 1459-1511.

38 J. J. Concepcion, J. W. Jurss, M. K. Brennaman, P. G. Hoertz, A. O. T. Patrocinio, N. Y. M. Iha, J. L. Templeton and T. J. Meyer, Acc. Chem. Res., 2009, 42, 1954-1965.

39 E. C. Constable, Chem. Soc. Rev., 2007, 36, 246-253.

40 T. Pintauer and K. Matyjaszewski, Coord. Chem. Rev., 2005, 249, 1155-1184.

41 A. Winter, G. R. Newkome and U. S. Schubert, ChemCatChem, 2011, 3, 1384-1406.

42 S. D. Cummings, Coord. Chem. Rev., 2009, 253, 1495-1516.

43 I. Eryazici, C. N. Moorefield and G. R. Newkome, Chem. Rev., 2008, 108, 1834-1895.

44 K. Suntharalingam, D. J. Hunt, A. A. Duarte, A. J. P. White, D. J. Mann and R. Vilar, Chem. - Eur. J., 2012, 18, 1513315141.

45 S. Ghosh, O. Mendoza, L. Cubo, F. Rosu, V. Gabelica, A. J. P. White and R. Vilar, Chem. - Eur. J., 2014, 20, 4772-4779.

46 E. Largy, F. Hamon, F. Rosu, V. Gabelica, E. De Pauw, A. Guedin, J. L. Mergny and M. P. Teulade-Fichou, Chem. Eur. J., 2011, 17, 13274-13283.
47 H. Bertrand, D. Monchaud, A. De Cian, R. Guillot, J. L. Mergny and M. P. Teulade-Fichou, Org. Biomol. Chem., 2007, 5, 2555-2559.

48 P. R. Andres, R. Lunkwitz, G. R. Pabst, K. Bohn, D. Wouters, S. Schmatloch and U. S. Schubert, Eur. J. Org. Chem., 2003, 3769-3776.

49 W. Huang, W. You, L. Wang and C. Yao, Inorg. Chim. Acta, 2009, 362, 2127-2135.

50 A. W. Addison, T. N. Rao, J. Reedijk, J. van Rijn and G. C. Verschoor, J. Chem. Soc., Dalton Trans., 1984, 1349-1356.

51 A. M. Pyle, J. P. Rehmann, R. Meshoyrer, C. V. Kumar, N. J. Turro and J. K. Barton, J. Am. Chem. Soc., 1989, 111, 3051-3058.

52 N. Shahabadi and P. Fatahi, DNA Cell Biol., 2012, 31, 13281334.

53 E. C. Long and J. K. Barton, Acc. Chem. Res., 1990, 23, 271273.

54 P. M. Bradley, A. M. Angeles-Boza, K. R. Dunbar and C. Turro, Inorg. Chem., 2004, 43, 2450-2452.

55 J. K. Barton, A. T. Danishefsky and J. M. Goldberg, J. Am. Chem. Soc., 1984, 106, 2172-2176.

56 R. F. Brissos, E. Torrents, F. Mariana Dos, S. Mello, W. Carvalho Pires, E. de Paula Silveira-Lacerda, A. B. Caballero, A. Caubet, C. Massera, O. Roubeau, S. J. Teat and P. Gamez, Metallomics, 2014, 6, 1853-1868.

57 S. Kashanian, S. Javanmardi, A. Chitsazan, K. Omidfar and M. Paknejad, DNA Cell Biol., 2012, 31, 1349-1355.

58 F. J. Meyeralmes and D. Porschke, Biochemistry, 1993, 32, 4246-4253.

59 J. R. Lakowicz and G. Weber, Biochemistry, 1973, 12, 41614170 .

60 M. N. Dehkordi and P. Lincoln, J. Fluoresc., 2013, 23, 813821.

61 J. C. Peberdy, J. Malina, S. Khalid, M. J. Hannon and A. Rodger, J. Inorg. Biochem., 2007, 101, 1937-1945.

62 A. McCoubrey, H. C. Latham, P. R. Cook, A. Rodger and G. Lowe, FEBS Lett., 1996, 380, 73-78.

63 B. Halliwell and J. M. C. Gutteridge, Methods Enzymol., 1990, 186, 1-85.

64 G. R. Buettner, J. Biochem. Biophys. Methods, 1988, 16, 27-40.

65 A. V. Chernikov and V. I. Bruskov, Biofizika, 2002, 47, 773781.

66 L. Guilloreau, S. Combalbert, A. Sournia-Saquet, H. Mazarguil and P. Faller, ChemBioChem, 2007, 8, 13171325.

67 J. Granifo, G. Ferraudi and D. P. Rillema, J. Photochem., 1983, 23, 51-60.

68 S. Kapoor and M. S. Sastry, Int. J. Chem. Kinet., 2000, 32, 92-98.

69 K. J. Catalan, S. Jackson, J. D. Zubkowski, D. L. Perry, E. J. Valente, L. A. Feliu and A. Polanco, Polyhedron, 1995, 14, 2165-2171.

70 SADABS, SAINT and SHELXTL, Bruker AXS Inc., Madison, Wisconsin, USA.

71 G. M. Sheldrick, Acta Crystallogr., Sect. A: Fundam. Crystallogr., 2008, 64, 112-122. 